\title{
Moderating Effects of Service Separation on Customer Relationships with Service
}

\section{Firms: A Social-Exchange Perspective}

Purpose - This paper examines the impact of service separation on the ability of service firms to build and maintain customer relationships, by exploring the differences in the strength of interrelationships among key relational constructs between separated and unseparated service delivery modes.

Design/methodology/approach - A field-survey was conducted with retail banking customers in Saudi Arabia (N=592) using a structured self-administered questionnaire consisting of well-established scales. Data was analyzed using AMOS 24.

Findings - Service separation negatively moderates (weakens) the ability of the service firms to leverage their social benefits, relational trust and affective commitment to increase customer loyalty and to strengthen overall customer relationships.

Research limitations/implications: This study uses retail banking customers in Saudi Arabia to test the impact of service separation in their relationship with the bank, hence its findings may not be generalizable to other types of services and cultural settings.

Practical implications - Service firms using online and mobile technologies should be aware that trust and commitment remain key to building customer loyalty. Hence, the trade-off between the benefits of these technologies and their negative impact on customer relationship needs to be factored into managerial decision making.

Originality/value - The paper highlights the importance of maintaining face-to-face interactions with service customers to create robust relationships that yield loyalty, despite the growing popularity of online and mobile technologies.

Keywords: affective commitment, customer loyalty, relational trust, service separation, social benefits

Paper type: Research paper 


\section{Introduction}

During the last few decades, scholars have identified customer relationships to be one of the most important elements of marketing strategy (Ashley et al., 2011; Berry, 1983; Giovanis et al., 2015; Gummesson, 2002; Morgan and Hunt, 1994; Palmatier et al., 2006; Verma et al., 2016). The abundance of literature devoted to relationship marketing (RM) (e.g. Åkerlund, 2005; Bowden et al., 2015; Dwyer, et al., 1987; Halinen and Tähtinen, 2002; Kingshott and Pecotich, 2007; Morgan and Hunt, 1994) reveals the importance of nurturing customer relationships to help improve customer satisfaction and long-term profitability (Aurier and N'Goala, 2010; Grönroos, 1994; Sheth and Parvatiyar, 1995). However, the emergence and growing use of mobile and online technological platforms by service firms to engage with the customer have also changed the underlying dynamics in building service relationships with them (Ramaseshan, Kingshott and Stein, 2015), due to the accompanying service separation (i.e. Keh and Pang, 2010).

Service separation resulting from customers using these and others forms of selfservice technologies (SSTs) is a relatively nascent field of study in the discipline. However, the effects of separation is critical to understand because those relational efforts directed at "attracting, maintaining and-in multi-service organizations-enhancing customer relationships" (Berry, 2002; p.61) must also account for the impact SSTs potentially have on the RM efforts of the service firm. Indeed, the need for more empirical studies specifically focusing on service separation is no more typified than in the recent call for further research "to better understand how spatial and/or temporal separation (or other psychological distances) manifest for consumers engaging with pure SSTs (e.g. self-service retail checkouts) by comparison to other forms of virtual and face-to-face service provision" (Harley and Green, 2017; p.378). 
Given the ongoing significance of RM in the services discipline there is surprisingly no studies specifically examining the impact that separated verses un-separated services have on the formation and maintenance of service relationships. This gap is critical to address since SSTs that underpin separation are not only intrinsically attractive for the service firm to deploy as they help reduce costs and improve productivity (Curran and Meuter, 2005) but potentially enhance the customer relationship because SSTs can help enrich the customer experience (Meuter, et al., 2000; Verhoef, et al., 2009).

The limited research shows service separation to play a moderating role during the service encounter (e.g. Walsh, Schaarschmidt and Ivens, 2018; Zhou et al., 2014) and a promising avenue to pursue as much of the empirical RM literature that has been grounded in social exchange (SE) (e.g. Kingshott and Pecotich, 2007; Morgan and Hunt, 1994) signifies that successful relationships are largely a function of the personal interactions between service employees and customers. More specifically, since service interactions are extensively social encounters (Malhotra et al., 2005) and therefore help build trust and commitment towards the service firm this potentially means that the impact of service separation on these underlying rudiments of the customer relationship needs examining. Green, Hartley and Gillespie (2017; p.481) find for example that "an element of depersonalization due to the lack of direct touch and face-to-face contact" results during the consumption of online health services.

Therefore to address this important gap in the services marketing literature and help understand the impact of separated verses un-separated modes of customer interaction on the overall customer relationship, we re-examine the RM literature (e.g. Åkerlund, 2005; Bowden et al., 2015) and integrate it with the SST (e.g. Barua, Aimin, and Hongyi, 2018; 
Bitner et al., 2000) and emergent service separation (e.g. Green, Hartley and Gillespie, 2016; Keh and Pang, 2010) literatures.

We have needed to build on previous RM studies in order to examine how service separation impacts customer perceptions about the overall service relationship because current SST literature largely focuses upon the service firm-customer interface and the potential impact this has on customer experiences (e.g. Meuter, et al., 2000; Verhoef, et al., 2009) but unfortunately fails short in examining how separation impacts the broader relationship. Specifically, we draw upon service separation and RM literatures to examine how service separation impacts the banking customer's view of the social benefits, trust, commitment and loyalty directed towards their banks. Whilst these are largely established relationships in the literature and thus underpin service relationships to the best of our knowledge this is the first attempt at specifically investigating how service separation (i.e. separated verses un-separated) impacts the inter-relationships between critical relational constructs.

This research also helps address the managerial challenge facing many service firms that either have or wish to embark upon having a multi-channel presence, namely the need to better understand customer experiences across various channels (Sousa and Voss, 2006) at the same time as building long lasting customer relationships. Typically, since customers are inclined to make judgements about the service firm on the basis of their evaluation of both online and offline platforms (e.g. Cassab and MacLachlan, 2008; Wang et al., 2016) our findings provide managers an insight into how they can address the challenge of giving their customer a seamless service experience when offering services in both separated and unseparated modes (Bapat, 2017). 
The remainder of our paper is configured as follows. Next, we review the relevant literature on service separation and other relevant constructs, to discuss the conceptual foundations of our study and to develop our conceptual model and specific hypotheses. We then describe our empirical study with retail-banking customers in Saudi Arabia, a cultural context where interpersonal interactions are an integral part of most service encounters. We test these ideas in the retail-banking context because this industry is often regarded as an innovator in using SSTs in the service encounter (Curran and Meuter, 2005) and as such depends heavily on self-service technologies (e.g., online banking) for their service offerings, and hence, it is important to know the likely effects of service separation on the banks' relational building efforts. Finally, we discuss the theoretical contribution and managerial implications of our findings along with some limitations of our study and directions for future research.

\section{Conceptual Background and Hypotheses}

Service separation and the customer relationship

The introduction of mobile and online platforms, as well as other forms of new technologies into the service relationship is primarily aimed at enhancing the customer experience at the same time helping service firms improve their productivity (e.g. Curran and Meuter, 2005; Meuter, et al., 2000; Ramaseshan, Kingshott and Stein, 2016). This firmcustomer interface results in service separation - defined as 'consumers' absence from service productions" (Keh and Pang, 2010, p.55), that can manifest as spatial and/or temporal separation within the service customer relationship (Harley and Green, 2017). To date, studies related to SSTs have focused upon a range of important areas within the services marketing domain such as customer usage patterns (Meuter et. al., 2005), customer satisfaction (Paluch and Blut, 2013), e-service quality (Parasuraman et al., 2005) and service 
recovery (Singh and Crisafulli, 2016), among others. This growing body of research has greatly enhanced our understanding of this important direction in services marketing however, no studies specifically examine how service separation impacts overall customer relationships.

RM literature suggests firms must constantly maintain and nurture their customer relationships to prevent them fading over time and this also helps ensure customer loyalty and commitment ( $\AA$ kerlund, 2005; Bowden et al., 2015; Halinen and Tähtinen, 2002). Customer relationships that involve face-to-face interactions can draw upon social exchange (SE) theory (Thibaut and Kelley, 1959) to help conceptualize how high levels of personalized interaction between the customers and service employees (Gwinner et al., 1998) through such interactions the opportunity arises to build mutual trust and commitment (Dwyer et al., 1987). Given the significance of RM within the discipline and the proliferation of online and mobile self-service (SSTs) technologies (Lin and Hsieh, 2012; Singh and Crisafulli, 2016), there is a clear need to examine the potential adverse impact that the associated service separation (i.e. disconnecting customers from the service employee) on customer satisfaction and loyalty. In fact, understanding how firms can enhance firm-customer relationships through technologyenabled services has been identified as one of the strategic priorities for future service research (Ostrom, et. al., 2015, p.143) so in light of the long standing link between satisfaction and loyalty there is a clear need to understand the impact of separation on that relationship. Moreover, recent studies suggest service separation caused by the indiscriminate use of self-service technologies could have unintended customer relationships repercussions by disrupting the social exchange process needed to develop mutual trust and commitment (Green et al., 2016; Hartley and Green, 2017). Since these constructs underpin quality customer-firm relationships (Gwinner et al., 1998; Hennig-Thurau et al., 2002; Shin et al., 
2017) there is a need to re-examine these in light of the separation consequences of self service technologies.

Therefore understanding the effects of SST based service separation is particularly important for those service relationships that have traditionally been based upon face-to-face interactions due to the social benefits that personal interactions can yield (Gwinner et al., 1998). Interpersonal interactions have historically represented an important way in which the firms are used to building and maintaining long-term relationships with their customers (Palmatier et al., 2006) but managers also need to understand how mobile and online technologies impact the overall customer relationship.

Given the importance of these new technologies to the service operation a body of research investigating the potential effects of service separation that accompanies SSTs has begun to emerge (e.g. Keh and Pang, 2010; Paluch and Blut, 2013; Green, Hartley and Gillespie, 2016; Hartley and Green 2017; Walsh, Schaarschmidt and Ivens, 2018). Keh and Pang (2010) examine the effects of spatial separation (i.e. at a distance) on both access and convenience benefits derived through the service offering, as well as judgements about the performance risk of the service provider. More recently, Hartley and Green (2017) develop a framework that helps to better understand how spatial and/or temporal separation impact customer service evaluations. Whilst these and emerging works are important contributions in helping understand the effects of service separation on how customers evaluate the service offering they fail to explain how separation impacts the overall customer relationship.

If service firms wish for RM to continue to be the cornerstone of their marketing strategy then the potential impact service separation may have upon its rudiments, namely trust and commitment derived through social processes (e.g. Doney and Cannon, 1997; Dwyer, Schurr and Oh, 1987; Swan and Nolan, 1985) needs to be clearly understood. Since 
underlying social processes associated with the SE perspective of RM are unattainable during service separation this potentially means that the indiscriminate and unregulated adoption of SSTs may have serious consequences for the service firms' efforts to build relations with their customers. If this means that separated service has the net effect of reducing social benefits normally associated with interpersonal interactions (Johns and Perrott, 2008) this potentially denotes separation has a negative influence not only on the process by which new customer relationships are formed but also on the overall quality of both existing and new relationships (Bhappu and Schultze, 2006; Yen and Gwinner, 2003).

We now provide a synopsis of existing studies pertaining to the domain of relationship marketing to help develop our conceptual model that hypothesizes how service separation is intertwined with the core relational constructs (social benefits, trust and affective commitment) that underpin the capacity of the service firms to build loyal customers.

\section{Social Benefits}

According to SE theory, customer relationships are highly interactive in nature (Ashnail et al., 2016; Dwyer et al., 1987; Gummesson, 1987) and they yield many economic and social benefits. In interpersonal face-to-face services settings, customer benefits mainly relate to the core service offering but due to the nature of the interactive experience they also include confidence, social and special treatment benefits (Gwinner et al., 1998). Although confidence benefits are consistently shown as important outcomes for customers (Gwinner et al., 1998; Kinard and Capella, 2006), the presence of social benefits is particularly significant in building and maintaining successful customer relationships due to elevated interpersonal contact with the employees (Gwinner et al., 1998). Social benefits to help strengthen the customer relationship given "service encounters are first and foremost social encounters" (McCallum and Harrison, 1985, p 35). This has much support in the literature. For example, 
the interactive nature of SE based relationships increases trust and commitment (Dwyer et al., 1987; Moorman et al., 1993; Turnbull et al., 1996; Yilmaz et al., 2005) at the same time helps to provide a variety of social benefits to the customer (Candi and Kahn, 2016; Keh and Pang, 2016; Verma et al., 2016).

Moreover, the accumulation of successful service encounters not only enhances customer satisfaction and loyalty but aids with building longer term customer relationships (Czepiel, 1990). We argue customer relationship are enhanced when social benefits are present in the service encounter because these contain feelings of familiarity, personal recognition, friendship, rapport, and social support. It is through these particular SE dimensions that long lasting relationships can be built (Gwinner et al., 1998: Hennig-Thurau et al., 2002). Therefore, we posit social benefits of customers' relationships with their service providers (e.g. familiarity, recognition and friendship) potentially act as the drivers of relational trust, affective commitment and customer loyalty.

\section{Relational Trust and Affective Commitment}

In much of the relationship marketing literature, trust is defined as "a willingness to rely on an exchange partner in whom one has confidence" (Moorman et al., 1992; p.315) and its presence invariably results in commitment, depicted as "an exchange partner believing that an ongoing relationship with another is so important as to warrant maximum efforts at maintaining it" (Morgan and Hunt, 1994; p.23). Trust and commitment are central aspects of SE-based relationships (Bendapudi and Berry, 1997; Morgan and Hunt, 1994; Gundlach et al., 2005), hence their presence in the customer relationship signifies that the RM efforts of the firm were successful (e.g. Doney and Cannon, 1997; Dwyer et al., 1987; Garbarino and Johnson, 1999). 
Trust comprises=a belief directed towards another (Moorman et al., 1993) and can include, among others trust in individuals (Swan and Nolan, 1985), organizations (Morgan and Hunt, 1994), other customers (Furner et al., 2016) or even technology (Johnson et al, 2008). In this research, we depict trust to be directed towards the service firm which is shown to be a key driver of relationships within the banking context (Van Esterik-Plasmeijer \& Fred van Raaij, 2017). It is in the bank setting that we then examine how service separation impacts the well documented trust-commitment link.

Commitment has been conceptualized in the literature in a number of ways. For example, it can comprise affective, normative and continuance types (Allen and Meyer, 1990); instrumental, behavioral intent and temporal dimensions (Gundlach et al., 1995); and even calculative, affective and normative elements (Čater and Zabkar, 2009), among others. Our research adopts Allen and Meyers' (1990) affective commitment perspective as that best characterizes SE relationships because it reflects an emotional attachment, identification and involvement with an organization (Allen and Meyer, 1990, 1996; Meyer and Herscovitch, 2001). Typically, in interpersonal services settings, affective commitment is highly correlated to the degree of interaction and social bonding between the exchange partners ( $\breve{C}$ ater and Zabkar, 2009), which involves personal contact and it is that that is critical in helping to build personal obligation, trust, and commitment (Blau, 1964; Cropanzano and Mitchell, 2005).

In service settings, social interaction is often a key determinant in contributing to successful customer relations (Berry, 1995; Price and Arnould, 1999; Vargo and Lusch, 2008) and it also helps establish the foundations of SE based relationships, namely, trust and commitment. Trust and commitment require cooperation and interdependence between parties (Johnson-George and Swap, 1982) which is a hallmark of face-to-face service encounters, suggesting service separation may have negative implications for their presence 
and impact within the overall service relationship. These two relational ingredients result from a cumulative interaction process (Doney and Cannon, 1997; Dwyer et al., 1987) that heightens through successful interactions (Nicholson et al., 2001), such as successful ongoing service episodes. The evidence showing the link between trust and commitment in service settings (e.g. Moorman, Zaltman and Deshpande, 1992; Li, 2015) culminates in commitment acting as a binding force that holds parties together (Meyer and Herscovitch, 2001), infers these constructs yield loyalty within the service relationship.

Customer Loyalty

Loyalty is defined as "a deeply held commitment to rebuy or repatronize a preferred product/service consistently in the future" (Oliver, 1999. p. 34) and contains both attitudinal and behavioral elements (Hennig-Thurau et al., 2002). The ability of the service firm to leverage trust and commitment to gain loyal customers is tantamount given the main aim of $\mathrm{RM}$ and service strategies is for the service firms to keep customers forever (Aurier and N'Goala, 2010). Indeed, loyalty is the primary goal of a firms RM efforts (Hennig-Thurau et al., 2002) and is critical for both profitability and perceived firm performance (Krishnamurthi and Raj, 1991; Reinartz and Kumar, 2002; Rauyruen and Miller, 2007) as well as helping to increase revenue, generate positive advocacy, and reduce costs associated with serving customers (Hennig-Thurau et al., 2002; Kursunluoglu, 2014).

Since the earlier work of Dick and Basu (1994), it is of little surprise then that customer loyalty has been widely researched in many service contexts (e.g. Auh et al., 2007; Ball et al., 2004; Ou et al., 2016; Sajtos et al., 2015; Yim et al., 2008). However, the introduction of self-service technologies has changed the nature of the firm-customer interface (Lin \& Hsieh, 2012; Ramaseshan, Kingshott \& Stein, 2015) thus requires a reexamination of capacity of the traditional relational framework in helping to build customer 
loyalty. Clearly the relationship marketing $(\mathrm{RM})$ paradigm has been an important framework in helping explain firm-customer relationships. However given SSTs result in service separation, and that potentially eliminates the critical social processes underpinning RM, the continual relevance of this perspective in helping explain the firm-customer relationship needs to be questioned. Specifically, whether mobile and online technology induced service separation reduces the capacity of the service firm to build trust based commitment to attract loyal customers. In the next section, we discuss service separation then build on that to explain how the moderating effects of service separation impacts the link between core SEbased relational constructs.

Service Separation

Inseparability is one of the key characteristics of interpersonal services (i.e. inseparable from the service provider) thus requiring a physical presence and simultaneous interaction between the customers and service employees (Bendapudi and Leone, 2003; Gwinner et al., 1998; Zeithaml et al., 1985). Such interactivity is also a function of the value co-creation process and is an integral part of customer relationship management (Vargo and Lusch, 2004). Service inseparability, provides a critical opportunity for the service firm to build and maintain meaningful customer relationships (Blut et al., 2014; Ennew and Binks, 1999; Sierra and McQuitty, 2005), and these are largely characterized by face-to-face interactions between the customer and service employee. The high degree of interpersonal communication and interaction helps build customer trust and commitment (Doney and Cannon, 1997; Dwyer et al., 1987). The underlying assumptions that underpin SE relationships are inherent moral obligations between actors involving reciprocity and reinforcing interdependence through socialization between the parties (Kingshott, 2006, p.726). Interpersonal service encounters play a central relational building role during the 
value co-creation process (Vargo and Lusch, 2008) so the introduction of new technologies that encourage service separation now means customers can still co-create value but without having any direct face-to-face contact with the organization (Lovelock and Gummesson, 2004) and/or its personnel (Bitner et al., 2000).

This means service separation has potential relational consequences because interpersonal connections that characterize SE relationships may be partially or fully severed in accordance with the customer's mode(s) of interaction with the service firm (Keh and Pang, 2010). Hence, it is not surprising to see a relatively higher likelihood of customer defection during the early stages of introduction of self-service channels (Scherer et al., 2015) and feeling of disengagement for service providers who are physically separated from their customers (Green, Hartley and Gillespie, 2016). The key question arising in the context of this research is whether service separation has any longer term implications for the overall relationship. One clue is offered by Hartley and Green (2017) who show that consumers may feel psychologically distant from the service firm in response to service separation and hence, spatial (but not temporal) separation could have a significant negative effect on consumers' evaluations of service experiences (Hartley and Green, 2017).

Thus by taking service personnel out of the equation, the very nature of the service offering and its associated delivery processes are potentially different (Bitner et al., 2000; Paluch and Blut, 2013) to those typically explained by the IHIP (intangibility-heterogeneityinseparability-perishability) framework (Zeithaml et al., 1985). This in effect means that separated services may not only epitomize how customer interactions have changed but also infer potential negative RM connotations for the service firm (Baird et al., 2014; Keh and Pang, 2010; Paluch and Blut, 2013). More specifically, those social interactions that normally have positive effects on trust, commitment and customer relationships are mostly absent from 
technology-driven service encounters (Gwinner et al., 1998; Hennig-Thurau et al., 2002) so the impact of separated services on the RM building efforts of the service firm need to be empirically examined.

To summarize, interpersonal interactions and communication play a major role in building customer trust, commitment, and loyalty (Drolet and Morris, 2000; Johns, 2012; Morgan and Hunt, 1994) and hence, service separation could potentially prevent the service organization from optimizing its relational building capacity. It is thus proposed herein that separated services affects the capacity to leverage social interactions and this impedes the ability of the service firm to develop trust-based commitment as a means of acquiring loyal customers. The theoretical underpinnings of these links are discussed next.

\section{Moderating Effects of Service Separation}

Service separation has been found to encompass both positive and negative consequences on how customers assess the service firm. For example, Keh and Pang (2010) regard service separation to be a double-edged sword because it can help to improve (assess and benefit) convenience for customer but at the same time elevate perceived risk in the service offering. In another study specifically examining the moderating effect of separation, Walsh, Schaarschmidt and Ivens (2018) find service separation to enhance the link between a customers' perceived value of the service (conceptualized as overall utility) and the value one a particular customer to the service organization when the customer engages offline (separated) with the service provider. Most recently, Hartley and Green (2017) examine how spatial and temporal separation impacts customer perceptions of the service offering and conclude that separation results in a service separation/customer integration paradox. Once again these authors reveal how separation has potential dual positive and negative consequences for the customer and how they could perceive the service firm. 
Interestingly, Hartley and Green (2017) suggest that when technology is part of the service offering then providers need to seriously consider initially meeting with customers on a face-to face basis to simultaneously establish rapport and mitigate potential negative consequences of separation, showing the need to factor the consequences of separation into the overall relational building efforts of the service firm. This assertion has some empirical basis. For example, Chen, Wu and Chien (2016) find in the banking sector that the level of initial trust towards the financial institution increases customer involvement with the institution but perhaps more significantly this is critical for new product success. Whilst their research shows the importance of trust as both antecedent and intrinsic to the success of the overall relationship it also alludes us to the need to somehow embed social exchange processes that underpin trust into the technology infused service experience. Failure to do so potentially means that service separation can dampen the broader relational ambitions of the service organization, so the introduction of SSTs' into the operation need to be managed correctly.

We explore these relational consequences herein by examining whether service separation acts to dampen the capacity of the service firm to nurture trust and commitment in the relationship. Since previous literature indicates that since "service encounters are first and foremost social encounters" (McCallum and Harrison, 1985, p. 35) we do anticipate many of the social benefits associated with face-to-face interactions would potentially diminish under separation conditions. This is important to understand because the presence of social benefits has a positive bearing on perceived relationship quality (Hennig-Thurau et al., 2002) and their absence has the opposite effect (Bhappu and Schultze, 2006; Yen and Gwinner, 2003). Typically, in service settings, relationship quality is characterized to comprise trust and commitment (Berry, 1995; Dagger and O’Brien, 2010; Gwinner et al., 1998) thus implying 
social interactions and associated benefits are also central to successful longevity of the service relationship.

Since conventional service wisdom advocates that a prosperous RM strategy is based upon a customer interface that is both interactive and face-to-face in nature (Black et al., 2014), then intuitively a separated service that decouples the personalized experience would undermine the basic rudiments of successful SE relationships. However, a service provider's role needs to be more expansive than just delivering value offerings (that is relationshipfocused) because it needs to include facilitates that support the ongoing service experience (Tsiotsou, 2016; p.92). It is through these interactive service elements, that service relationships with high levels of personalized contact will result in higher social benefits to the customer (Kinard and Capella, 2006). Conversely, by creating 'distance' between the customers and service employees through service separation this could reduce the capacity of the service firm to fully leverage the potential of the SE relationship (Black et al., 2014). This implies that in a separated service context, even if the service firms provides ample social benefits, these may not result in relational trust and affective commitment because of a lack of social interactions that underpin SE-based relationships. Accordingly, we hypothesize as follows:

H1: The positive effect of social benefits on relational trust is stronger under unseparated versus separated modes of service delivery.

H2: The positive effect of social benefits on affective commitment is stronger under unseparated versus separated modes of service delivery.

Marketing literature is abundant with empirical studies showing the direct positive influence of trust on commitment (e.g. Aurier and N'Goala, 2010; Kingshott and Pecotich, 2007; Moorman et al., 1992; Morgan and Hunt, 1994) and in particular how the interactive effects 
intrinsic to close interpersonal is critical to the formation of these two constructs (Geyskens et al., 1996). On the basis of the above discussion, we argue that due to the social nature of interpersonal service relationships, a separated service that decouples this 'social link', would effectively reduce the opportunity for the service firm to optimize the ability of trust to nurture commitment (Bowden et al., 2015). In other words, even if the customers have trust in their relationship with the service provider, it would be very difficult for this to be translated into affective commitment in a separated service context because of the lack of opportunity for socialization and close interactions that underpin the SE based relationship (Garbarino and Johnson 1999; Geyskens et al., 1996). Hence, we hypothesize as follows:

H3: The positive effect of relational trust on affective commitment is stronger under unseparated versus separated modes of service delivery.

Both trust and commitment are repeatedly shown to have a positive effect on customer loyalty, although the precise relationship between these constructs is somewhat unclear (e.g. Athanasopoulou, 2009; Coelho and Henseler, 2012; Paulssen et al., 2014; Pritchard et al., 1999). In this context, some studies show relationship commitment as an important mediator between trust and customer retention (Aurier and N'Goala, 2010; Doney and Cannon, 1997; Hennig-Thurau et al., 2002; Sirdeshmukh et al., 2002; Harris and Goode 2004), whereas others indicate that trust has a more direct effect on customer loyalty ( $\breve{C}$ ater and Čater, 2009; Sirdeshmukh et al., 2002). Indeed, Reichheld and Schefter (2000) note in order "to gain loyalty of customers, you must first gain trust" (p.107). In a similar vein, commitment is also shown to be an important factor in building strong customer loyalty (Prichard et al., 1999).

Based on numerous empirical studies, it is fairly evident trust and commitment are central to the formation and maintenance of strong and long lasting SE-based relationships, and that, both constructs have a pivotal role to play in helping build loyal customers. We 
argue however that by separating the customers from the service employees this weakens the impact of relational trust and affective commitment due to a lack of face-to-face interpersonal interactions, limiting the ability of the customers and service employees to form close social bonds (Ashley et al., 2011; Ashnai et al., 2016; Aurier and N'Goala, 2010). In other words, even if the service firms are able to build relational trust and commitment using self-service technology, they may not be able to translate these into customer loyalty ( $\AA$ kerlund, 2005; Ball et al., 2004; Bendapudi and Berry, 1997) because customers may not feel obligated to continue patronizing the service firm in the absence of any social exchange based relationship with the service employees. Based on this discussion, we hypothesize:

H4: The positive effect of relational trust on customer loyalty is stronger under unseparated versus separated modes of service delivery.

H5: The positive effect of affective commitment on customer loyalty is stronger under unseparated versus separated modes of service delivery.

$<$ Insert Figure 1 about here $>$

\section{Methodology}

\section{Research Setting and Design}

To test all the hypotheses (Figure 1), this study uses data collected from a survey of retailbanking customers in Saudi Arabia, with a structured self-administered questionnaire. The questionnaire was initially developed in English and pre-tested with native English-speaking customers in Australia. Next, it was translated into Arabic using Douglas and Craig's (2007) methodology as their collaborative and iterative approach addresses the weaknesses of the traditional back translation method. The questionnaire was translated by two linguistics experts who specialize in English-Arabic translations. A joint meeting was held to decide on 
a common final version. This was important to establish because as there are some minor variations in the Arabic language spoken in Saudi Arabia it helped ensure that the instrument could be readily understood by all potential respondents. Further to this, additional pretesting was carried out in Arabic with two groups of bank customers representing two regional cities in Saudi Arabia. Consequently, one trust indicator (I have great confidence in my bank) was eliminated due to semantic reasons associated with the Arabic language. The questionnaire (see Appendix 1 for English version) was finally approved by both linguistic experts prior to the launch of data collection.

\section{Measures}

The questionnaire consists of existing scales adapted from extant literature, congruous with this study's objectives and context, including. A five-item scale for social benefits from the Gwinner et al., (1998) scale of relational benefits and a six-item scale for trust using Morgan and Hunt (1994) scale was used. The five-item scale used to measure affective commitment was adopted from Bansal et al., (2004) and Davis-Sramek et al., (2009), both of which are based on the original scale developed by Allen and Meyer (1990). Items measuring loyalty (4-items) were adopted from Hennig-Thurau et al., (2002) and Bell et al., (2005), both of which incorporated elements of behavioral intentions introduced by Zeithaml et al., (1996). All these scales were used with seven-point Likert type response formats, with "strongly disagree" (1) and "strongly agree" (7) as anchors. To operationalize 'service separation', the respondents were asked to identify which methods of banking they commonly used from the following options: physical branches (unseparated), phone and online banking (separated), and "other methods" which includes ATMs or any other unspecified method. Based on these responses the data was split into two groups, separated $[\mathrm{S}]$ and unseparated $[\mathrm{U}]$ service mode.

Sample and Procedure 
Bank customers from eleven retail bank branches in Saudi Arabia were approached to assist in data collection. These branches represent five different banks, including two Islamic banks. Furthermore, to provide a greater coverage, the branches are located in three different cities (Riyadh; Dammam; and, Hafr Al-Batin). Staff in each branch invited customers to participate in the study on a voluntarily basis. Such a snowballing approach is a common technique in instances where data from customers is collected in both B2B and B2C settings (e.g. Tate, Ellram and Brown, 2009; Chakravarty, Kumar and Grewal, 2014; Gaur, et al., 2017), therefore we were confident in our results. Moreover, the assistance of banks' employees was vital to gather data - particularly in female-only branches, which are quite unique to the Saudi Arabian context. Data collection yielded a total of 680 responses which was subject to screening and manipulation checks. First, 27 responses were eliminated, comprising customers that did not either use physical branches, online or phone banking methods to conduct transactions. Following Tabachnick and Fidell (1996) we also identified responses with extensive non-random missing values as well as uni and/or multivariate outliers. As a result of this analysis, further 61 cases were excluded from the data-set. Of the 680 collected surveys, a total of 592 were deemed useable for the analysis. Out of these 228 respondents indicated a preference for using bank branches (unseparated), and 364 used either online banking or phone banking (separated) as their preferred method of interaction, therefore all the samples meet the minimum threshold for analysis (e.g. Hair et al., 2010).

\section{Data Analysis and Results}

We used the well-established two-step process recommended by Anderson and Gerbing (1988) to estimate the measurement and structural models, using a multi-group structural equation modeling approach with AMOS 24. The initial measurement model for the two groups (separated and unseparated) showed a relatively poor fit $\left(\chi^{2}=865.18, \mathrm{df}=328, \chi^{2} / \mathrm{df}=\right.$ 
2.64, RMSEA $=.043, \mathrm{SRMR}=.039, \mathrm{NFI}=.92, \mathrm{CFI}=.95, \mathrm{TLI}=.94)$ based on the criteria suggested for model fit with sample sizes exceeding 350 (Hair et al., 2010). Hence, we used modification indices to correlate four pairs of error terms with each other and the reduced measurement model shows a better fit $\left(\chi^{2}=610.84, \mathrm{df}=310, \chi^{2} / \mathrm{df}=1.97, \mathrm{RMSEA}=.042\right.$, $\mathrm{SRMR}=.032, \mathrm{NFI}=.95, \mathrm{CFI}=.97, \mathrm{TLI}=.96)$. Table 1 shows all the scale items and their standardized parameter estimates (factor loadings) for the two groups.

$<$ Insert Table 1 about here $>$

Next, we tested convergent validity of all the constructs for the full sample as well as the unseparated and separated groups. All the scales have high composite reliabilities $(>.70)$ as shown in Table 2 (Fornell and Larcker, 1981) and the average variance extracted (AVE) for all the constructs are higher than .50 (Bagozzi and Yi, 1988). Hence, all the constructs exhibit convergent validity. Discriminant validity was also established as the square roots of AVE for all the constructs are higher than their correlation estimates with the other constructs, as shown in Table 2 (Farrel, 2010; Hair et al., 2010). Table 2 shows all the correlations, descriptives and composite reliabilities for all the constructs used in this study.

$<$ Insert Table 2 about here $>$

Finally, we tested all the five hypotheses using a three-step multi-group analysis of structural invariance (Dagger and Sweeny, 2007; Jin, et al., 2008; Dagger and O’Brien, 2010), to establish if there are significant structural differences between the customers using unseparated and separated modes of service delivery. We began by testing an unconstrained structural model in which all the path coefficients were allowed to vary across the two groups (i.e., unseparated and separated) and found a close fit to the data $\left(\chi^{2}=658.01, \mathrm{df}=316, \chi^{2} / \mathrm{df}\right.$ $=2.08, \mathrm{RMSEA}=.043, \mathrm{SRMR}=.033, \mathrm{NFI}=.95, \mathrm{CFI}=.97, \mathrm{TLI}=.96) . \mathrm{Next}$, we tested a constrained model in which all the path coefficients were constrained to be equal across the 
two groups and this model shows a significantly poorer fit $\left(\chi^{2}=686.52, \mathrm{df}=321, \chi^{2} / \mathrm{df}=\right.$ 2.14, $\mathrm{RMSEA}=.044, \mathrm{SRMR}=.035, \mathrm{NFI}=.94, \mathrm{CFI}=.96, \mathrm{TLI}=.95)$ compared to the unconstrained model $\left(\Delta \chi^{2}=58.01, \Delta \mathrm{df}=5, \mathrm{p}<.001\right)$. This suggests that there is an overall difference in the strength of the path coefficients between the unseparated and separated groups. To identify which of the specific paths differ significantly from each other, we conducted a structural invariance test for each path one by one (e.g., Chun and Davies, 2006; Jin et al., 2008). Table 3 shows the findings from this analysis.

$<$ Insert Table 3 about here $>$

Next, five different structural models were tested by constraining each hypothesized path one at a time and these results were compared against the unconstrained model. Four of the five paths (except H3) have significantly different path coefficients between the two groups. First, social benefits have a stronger positive effect $\left(\Delta \chi^{2}=19.36, \Delta \mathrm{df}=1, \mathrm{p}<.001\right)$ on relational trust for the unseparated $(\beta=.77, \mathrm{p}<.001)$ versus separated $(\beta=.38, \mathrm{p}<.001)$ group, hence $\mathrm{H} 1$ is supported. Similarly, social benefits have a stronger positive effect $\left(\Delta \chi^{2}=4.04, \Delta \mathrm{df}=\right.$ $1, \mathrm{p}<.05)$ on affective commitment for the unseparated $(\beta=.32, \mathrm{p}<.001)$ versus separated $(\beta=.22, \mathrm{p}<.001)$ group, hence $\mathrm{H} 2$ also finds support. However, there is no significant difference $\left(\Delta \chi^{2}=2.15, \Delta d f=1, p>.10\right)$ in the effect of relational trust on affective commitment between the two groups, hence H3 is not supported. Next, relational trust has a stronger positive effect $\left(\Delta \chi^{2}=7.84, \Delta \mathrm{df}=1, \mathrm{p}<.01\right)$ on loyalty for the unseparated $(\beta=.51$, $\mathrm{p}<.001)$ versus separated $(\beta=.26, \mathrm{p}<.001)$ group, supporting H4. Finally, affective commitment has a stronger positive influence $\left(\Delta \chi^{2}=15.76, \Delta \mathrm{df}=1, \mathrm{p}<.01\right)$ on loyalty for the unseparated $(\beta=.48, \mathrm{p}<.001)$ versus separated $(\beta=.24, \mathrm{p}<.001)$ group, hence H5 is also supported. In the next section, we discuss these findings and their implications. 


\section{Conceptual Contribution}

By revisiting the RM literature we are now able to better understand how service separation associated with the proliferation of new mobile and online self-service potentially impacts the relational capabilities of the service organization. Amid the increased use of self-service technologies, and the inherently limited personal interactions they engender, this study advances both Keh and Pang's (2010) and Harley and Green's (2017) call to further examine the effects of service separation. We test our model in the context of retail banking customers in Saudi Arabia.

As noted earlier, the marketing literature offers valuable but a limited perspective into the dynamics of the separated verses unseparated service experiences of customers on the overall service relationship they have with their service firms despite the increased use of various technology (e.g. Johns, 2012; Keh and Pang, 2010). Our study therefore provides a further insight into the dynamic nature of customer-firm relationships and their evolution in the context of today's digital age in which customers are choosing a range of mobile and online platforms to experience the service offering. Through this we are able to reveal how the subtleties of firm-customer relationships are also a function of the specific contexts services are being delivered and experienced, whether this is via multi-channels, unseparated or separated modes of service. To do this end, we have needed to draw upon RM literature to reveal the effects of service separation / non-separation modes of interaction on the capacity of the service organization to attain loyal customers.

Our findings reveal that the different service delivery modes (i.e. separated versus unseparated) affect the positive interrelationships among social benefits, relational trust, affective commitment and customer loyalty. We find all the interrelationships among these variables to be positive in both separated and unseparated service delivery modes, however 
our data reveals these are much stronger in the case of unseparated mode (i.e. conventional branch banking in the context of this study). This study corroborates Keh and Pang's (2010) assertion that separated services bring about unique and context-driven challenges, potentially overlooked when viewed through the traditional relational marketing lens.

Statistical comparison of the links between core relationship variables between the unseparated and separated groups reveals a significant impact of the service delivery mode on the relational efforts of the service firm, which is a useful insight from both, theoretical and practical perspectives. Despite the social disengagement accompanying a separated mode, our findings uphold previous studies that show social benefits contributing towards the customers' disposition to relationships with their providers (Dagger and O'Brien, 2010; Gwinner et al., 1998; Hennig-Thurau et al., 2002). Similarly, we find the positive effects of trust and affective commitment on customer loyalty to hold reasonably well across delivery contexts confirming the importance of these variables in building robust customer relationships. To this end, both constructs positively affect loyalty, consistent with previous studies (e.g. Athanasopoulou, 2009; Palmatier et al., 2006), but we reveal the strength of each of the paths leading to loyalty is contingent on the specific mode of service delivery. In broad terms the study findings show that the unseparated and separated samples differ along four out of five paths in the structural model.

First, the impact of social benefits on trust and affective commitment are significantly higher for the unseparated (vs. separated) service delivery mode. These differences are most likely attributable to elevated levels of uncertainty associated with the separated service experience. Previous studies indicate customers' perception of the risks and uncertainty can influence their levels of trust (McCole et al., 2010), in particular the link between trust and 
loyalty (Paulssen et al., 2014). Separated contexts do pose uncertainty as transactions are carried out via a technological medium with customers having lesser control over the process (Harridge-March, 2006). Understandably, such an increase in ambiguity and uncertainty dampens customer trust, irrespective of the social benefits they enjoy.

Second, both trust and affective commitment have positive effects on customer loyalty but these effects are also stronger for the customers who prefer unseparated (vs. separated) service delivery modes. Trust, in the separated sample has both direct and indirect (via affective commitment) influence on loyalty; both are statistically significant but relatively weak in comparison to the unseparated sample. Despite the differences in path strengths between separated and unseparated modes, both service domains still ultimately lead to committed customers. In other words, the interplay between the RM constructs associated with building and nurturing customer-firm relationships are noticeably sensitive to changes in service delivery methods. This of course is by no means terminal for the firm's relational efforts but rather indicates where managers need to direct their marketing efforts if they aim to optimize the strength of the customer relationship.

\section{Managerial Implications}

Our findings show that bank managers need to be aware of the consequences that service separation emanating from new and emergent technologies potentially has upon their relational building efforts. This is critical in building customer loyalty considering that a recent banking report indicates that over $50 \%$ of customers globally are unsure whether or not they will stay with their banks in the next six months despite the improvement in overall positive experiences with their banks (World Retail Banking Report, 2013, p. 5). Our findings suggest that such discontent is not a function of a mismatch between the providers' relational efforts and the mode of service delivery but rather related to the overall service 
being experience. In other words, banks need to broaden their marketing strategies to incorporate customer-centric approach that caters to both emotional and social needs of customers.

From a technology infused service offering some caution needs to be placed on not focusing too much on the functional and technical benefits of each service delivery modes but rather on attempting to widen the social benefits derived by the customers through their physical face-to-face interactions when they engage with the frontline service employees. Indeed our results show that all customers regard social benefits as an important dimension in their relationship with the bank albeit to varying degrees so in light of a separated service the challenge is how to configure the self-service option that maximizes opportunities to tap into these social benefits. In the specific context of our study, the apparent willingness of Saudi customers to disengage through their use of technologies only reflects a small part of the overall relationship they have with the bank. Hence, the cohort of customers we identify as valuing an unseparated service mode, clearly do not rely solely on technology as the only means of engagement, as they still visit branches occasionally. Saudi Arabian culture is predominantly high context in nature so managers operating under such social environments need to configure their operations to cater to this duality in engagement modes in the firmcustomer interface. On the other hand, firms operating in low context cultures are likely to have very limited personal contact with the customers meaning service managers need to be cognizant of the limited opportunity they have to take advantage of social benefits that stem directly through personal interaction.

Based on our findings, service providers (e.g., banks) may benefit from emphasizing social aspects in their customer relationships given their role in nurturing loyal customers. In other words, service firms should attempt to focus on building a social connection with their 
customers regardless of how they deliver the services. In high context cultures, customers still desire personal interactions and therefore likely to initiate and engage with the service firm. However, in low context cultural settings banks need to take more proactive initiatives to try and entice customers to engage. Service separation via phone or online banking does offer cost advantages to banks and functional benefits to customers, but social connections with the provider should not be neglected. Therefore, innovative approaches to customer engagement that yield social benefits to the customers irrespective of the delivery mode, (e.g., social media platforms or social networking tools to the customers to stay connected with the service firm) would help the service firms optimize their relational building efforts.

\section{Limitations and Future Research}

This study has a few limitations that future research may address. First, we use retail banking in Saudi Arabia as our research setting because its relatively stronger reliance on relationship building and social benefits helped us test the moderating role of service separation on customer relationships. However, this could potentially limit the generalizability of our findings because retail banking interactions tend to be largely need-based, whereas many forms of service relationships require ongoing interactions, either due to the chronological needs of the relationship and/or some legally binding contract that compels the customer to constantly interact. For example, services such as, higher education, telecommunications, insurance, and many professional services require protracted engagements in the relationship for either party (customer and firm) to fulfil each's obligations to one another. Therefore, future research could test our model with other services and cultural settings. Such studies would help find out if RM strategies can be universally applied to separated services, irrespective of the type of service and cultural environment. Second, in this research we focused on the relational approach to building customer loyalty by studying the moderating 
impact of service separation on the mediating roles of trust and affective commitment.

However, there are many other variables that could reflect the success of the firm's relational efforts, including purchase intentions, word-of-mouth, share-of-wallet, convenience, satisfaction and customer reactions to service failure. Hence, future research could extend our model using these variables as customer outcomes.

\section{References}

Åkerlund, H. (2005), "Fading customer relationships in professional services", Managing Service Quality: An International Journal, Vol. 15 No. 2, pp. 156-171.

Allen, N.J. and Meyer, J.P. (1990), "The measurement and antecedents of affective, continuance and normative commitment to the organization", Journal of Occupational Psychology, Vol. 63 No. 1, pp. 1-17.

Allen, N.J. and Meyer, J.P. (1996), “Affective, continuance, and normative commitment to the organization: An examination of construct validity", Journal of Vocational Behavior, Vol. 49 No. 3, pp. 252-276.

Anderson, J.C. and Gerbing, D.W. (1988), "Structural equation modelling in practice: A review and recommended two-step approach“, Psychological Bulletin, Vol. 103 No. 3, pp. 411-423.

Ashley, C., Noble, S.M., Donthu, N. and Lemon, K.N. (2011), "Why customers won't relate: Obstacles to relationship marketing engagement", Journal of Business Research, Vol. 64 No. 7, pp. 749-756.

Ashnai, B., Henneberg, S.C., Naudé, P. and Francescucci, A. (2016), “Inter-personal and inter-organizational trust in business relationships: An attitude-behavior-outcome model“, Industrial Marketing Management, Vol. 52, pp. 128-139.

Athanasopoulou, P. (2009), "Relationship quality: A critical literature review and research agenda", European Journal of Marketing, Vol. 43 No. 5/6, pp. 583-610.

Auh, S., Bell, S.J., McLeod, C.S. and Shih, E., (2007), "Co-production and customer loyalty in financial services“, Journal of Retailing, Vol. 83 No. 3, pp. 359-370.

Aurier, P. and N'Goala, G. (2010), "The differing and mediating roles of trust and relationship commitment in service relationship maintenance and development", Journal of the Academy of Marketing Science, Vol. 38 No. 3, pp. 303-325.

Bagozzi, R.P. and Yi, Y. (1988), "On the evaluation of structural equation models", Journal of the Academy of Marketing Science, Vol. 16 No. 1, pp. 74-94. 
Baird, A., Raghu, T.S., North, F. and Edwards, F. (2014), "When traditionally inseparable services are separated by technology: The case of patient portal features offered by primary care providers“, Health Systems, Vol. 3 No. 2, pp. 143-158.

Ball, D., Simões Coelho, P. and Machás, A., (2004), "The role of communication and trust in explaining customer loyalty: An extension to the ECSI model", European Journal of Marketing, Vol. 38 No. 9/10, pp. 1272-1293.

Bansal, H.S., Irving, P.G. and Taylor, S.F. (2004), “A three-component model of customer commitment to service providers", Journal of the Academy of Marketing Science, Vol. 32 No. 3, pp. 234-250.

Bapat, D. (2017), "Exploring the antecedents of loyalty in the context of multi-channel banking”, International Journal of Bank Marketing, Vol. 35 No. 2, pp. 174-186.

Barua, Z., Aimin, W. and Hongyi, X. (2018), “A perceived reliability-based customer satisfaction model in self-service technology”, The Service Industries Journal, Vol. 38 No. 7-8, pp.446-466.

Bell, S.J., Auh, S. and Smalley, K. (2005), "Customer relationship dynamics: Service quality and customer loyalty in the context of varying levels of customer expertise and switching costs“, Journal of the Academy of Marketing Science, Vol. 33 No. 2, pp. 169-183.

Bendapudi, N. and Berry, L.L. (1997), "Customer's motivations for maintaining relationships with service providers“, Journal of Retailing, Vol. 73 No. 1, pp. 15-37.

Bendapudi, N. and Leone, R.P. (2003), "Psychological implications of customer participation in co-production“, Journal of Marketing, Vol. 67 No. 1, pp. 14-28.

Berry, L.L. (1983), Relationship marketing, in Berry, L.L., Shostack, G.L. and Upah, G. (Eds.), Emerging Perspectives on Services Marketing, Chicago, IL: American Marketing Association, pp. 25-28.

Berry, L.L. (1995), "Relationship marketing of services: Growing interest, emerging perspectives“, Journal of the Academy of Marketing Science, Vol. 23 No. 4, pp. 236-245.

Berry, L.L. (2002), "Relationship marketing of services perspectives from 1983 and 2000“, Journal of Relationship Marketing, Vol. 1 No. 1, pp. 59-77.

Bhappu, A.D. and Schultze, U. (2006), "The role of relational and operational performance in business-to-business customers' adoption of self-service technology“, Journal of Service Research, Vol. 8 No. 4, pp. 372-385.

Bitner, M.J., Booms, B.H. and Tetreault, M.S. (1990), "The service encounter: Diagnosing favorable and unfavorable incidents“, Journal of Marketing, Vol. 54 No. 1, pp. 71-84.

Bitner, M.J., Brown, S.W. and Meuther, M.L. (2000), "Technology infusion in service encounters“, Journal of the Academy of Marketing Science, Vol. 28 No. 1, pp. 138-149.

Black, H.G., Childers, C.Y. and Vincent, L.H. (2014), "Service characteristics' impact on key service quality relationships: A meta-analysis“, Journal of Services Marketing, Vol. 28 No. 4, pp. 276-291. 
Blau, P.M. (1964), Exchange and Power in Social Life. John Wiley and Sons, New York, NY.

Blut, M., Beatty, S.E., Evanschitzky, H. and Brock, C. (2014), "The impact of service characteristics on the switching costs-customer loyalty link“", Journal of Retailing, Vol. 90 No. 2, pp. 275-290.

Boshoff, C. (1997), "An experimental study of service recovery options“, International Journal of Service Industry Management, Vol. 8 No. 2, pp. 110-130.

Bowden, J.L.H., Gabbott, M. and Naumann, K. (2015), "Service relationships and the customer disengagement-engagement conundrum", Journal of Marketing Management, Vol. 31 No. 7, pp. 774-806.

Byrne, B.M. (2010), Structural Equation Modelling with AMOS: Basic Concepts, Applications, and Programming. 2nd ed., Routledge, New York, NY.

Candi, M. and Kahn, K.B. (2016), "Functional, emotional, and social benefits of new B2B services“, Industrial Marketing Management, Vol. 57, pp. 177-184.

Cassab, H. and MacLachlan, D L. (2009), “A consumer-based view of multi-channel service”, Journal of Service Management, Vol. 20 No. 1, pp. 52-75.

Čater, B. and Čater, T. (2009), "Emotional and rational motivations for customer loyalty in business-to-business professional services“, The Service Industries Journal, Vol. 29 No. 8, pp. 1151-1169.

Čater, B. and Zabkar, V. (2009), “Antecedents and consequences of commitment in marketing research services: The client's perspective“, Industrial Marketing Management, Vol. 38 No. 7, pp. 785-797.

Chakravarty, A., Kumar, A. and Grewal, R. (2014), "Customer orientation structure for internet-based business-to-business platform firms", Journal of Marketing, Vol. 78 No 5, pp. 1-23.

Chen, Y.H., Wu, J.J. and Chien, S.H. (2016), "Impact of initial trust, involvement, and mood on trusting belief: Evidence from the financial industry in Taiwan”, Journal of Service Theory and Practice, Vol. 26 No. 1, pp. 91-108.

Chun, R. and Davies, G. (2006), "The influence of corporate character on customers and employees: Exploring similarities and differences", Journal of the Academy of Marketing Science, Vol. 34 No. 2, pp. 138-146.

Coelho, P.S. and Henseler, J. (2012), "Creating customer loyalty through service customization“, European Journal of Marketing, Vol. 46 No. 3/4, pp. 331-356.

Cropanzano, R. and Mitchell, M.S. (2005), "Social exchange theory: An interdisciplinary review“, Journal of Management, Vol. 31 No. 6, pp. 874-900.

Curran, J.M. and Meuter, M.L. (2005), "Self-service technology adoption: Comparing three technologies", Journal of Service Marketing, Vol. 19 No. 2, pp. 103-113. 
Czepiel, J.A. (1990), "Service encounters and service relationships: Implications for research“, Journal of Business Research, Vol. 20 No. 1, pp. 13-21.

Dagger, T.S. and O'Brien, T.K. (2010), "Does experience matter? Differences in relationship benefits, satisfaction, trust, commitment and loyalty for novice and experienced service users“, European Journal of Marketing, Vol. 44 No. 9/10, pp. 1528-1552.

Dagger, T.S. and Sweeney, J.C. (2007), "Service quality attribute weights how do novice and longer-term customers construct service quality perceptions?” Journal of Service Research, Vol. 10 No. 1, pp. 22-42.

Davis-Sramek, B., Droge, C., Mentzer, J.T. and Myers, M.B. (2009), “Creating commitment and loyalty behavior among retailers: What are the roles of service quality and satisfaction? “ Journal of the Academy of Marketing Science, Vol. 37 No. 4, pp. 440-454.

Dick, A.S. and Basu, K. (1994), "Customer loyalty: Toward an integrated conceptual framework", Journal of the Academy of Marketing Science, Vol. 22 No. 2, pp. 99-113.

Doney, P.M. and Cannon, J.P. (1997), “An examination of the nature of trust in buyer-seller relationships“, Journal of Marketing, Vol. 61 No. 2, pp. 35-51.

Douglas, S. and Craig, C. (2007), "Collaborative and iterative translation: An alternative approach to back translation“, Journal of International Marketing, Vol. 15 No. 1, pp. 3043.

Drolet, A.L. and Morris, M.W. (2000), "Rapport in conflict resolution: Accounting for how face-to-face contact fosters mutual cooperation in mixed-motive conflicts", Journal of Experimental Social Psychology, Vol. 36 No. 1, pp. 26-50.

Dwyer, F.R., Schurr, P.H. and Oh, S. (1987), "Developing buyer-seller relationships“, Journal of Marketing, Vol. 51 No. 2, pp. 11-27.

Ennew, C.T. and Binks, M.R. (1999), "Impact of participative service relationships on quality, satisfaction and retention: An exploratory study", Journal of Business Research, Vol. 46 No. 2, pp. 121-132.

Farrell, A.M. (2010), "Insufficient discriminant validity: A comment on Bove, Pervan, Beatty, and Shiu (2009)", Journal of Business Research, Vol. 63 No. 3, pp. 324-327.

Fornell, C. and Larcker, D.F. (1981), "Evaluating structural equation models with unobservable variables and measurement error", Journal of Marketing Research, Vol. 18 No. 1, pp. 39-50.

Garbarino, E. and Johnson, M.S. (1999), "The different roles of satisfaction, trust, and commitment in customer relationships“", Journal of Marketing, Vol. 63 No. 2, pp. 70-87.

Gaur, S.S., Sharma, P., Herjanto, H. and Kingshott, R.P. (2017), "Impact of frontline service employees' acculturation behaviors on customer satisfaction and commitment in intercultural service encounters, Journal of Service Theory and Practice, Vol. 27 No. 6, pp. 1105-1121. 
Geyskens, I., Steenkamp, J., Scheer, L. and Kumar, N. (1996), "The effects of trust and interdependence on relationship commitment: A trans-Atlantic study", International Journal of Research in Marketing, Vol. 13 No. 4, pp. 303-317.

Giovanis, A., Athanasopoulou, P. and Tsoukatos, E., (2015), "The role of service fairness in the service quality-relationship quality-customer loyalty chain: An empirical study", Journal of Service Theory and Practice, Vol. 25 No. 6, pp.744-776.

Grayson, K. and Ambler, T. (1999), "The dark side of long-term relationships in marketing services", Journal of Marketing Research, Vol. 36 No. 1, pp. 132-41.

Green, T., Hartley, N. and Gillespie, N. (2016), "Service provider's experiences of service separation: the case of telehealth", Journal of Service Research, Vol. 19 No. 4, pp. 477494.

Grönroos, C. (1994), "From marketing mix to relationship marketing: Towards a paradigm shift in marketing", Management Decision, Vol. 32 No. 2, pp. 4-20.

Gummesson, E. (1987), “The new marketing: Developing long-term interactive relationships“, Long Range Planning, Vol. 20 No. 4, pp. 10-20.

Gummesson, E. (2002), "Relationship marketing in the new economy“", Journal of Relationship Marketing, Vol. 1 No. 1, pp. 37-57.

Gundlach, G.T., Achrol, R.S. and Mentzer, J.T. (1995), "The structure of commitment in exchange“, Journal of Marketing, Vol. 59 No. 1, pp. 78-92.

Gwinner, K.P., Gremler, D.D. and Bitner, M.J. (1998), "Relational benefits in services industries: The customer's perspective“, Journal of the Academy of Marketing Science, Vol. 26 No. 2, pp. 101-114.

Hair, J., Black, W., Babin, B. and Anderson, R. (2010), Multivariate Data Analysis: A Global Perspective, 7th global ed., Pearson Prentice Hall, Upper Saddle River, NJ.

Halinen, A. and Tähtinen, J. (2002), "A process theory of relationship ending“, International Journal of Service Industry Management, Vol. 13 No. 2, pp. 163-180.

Harridge-March, S. (2006), "Can the building of trust overcome consumer perceived risk online?” Marketing Intelligence and Planning, Vol. 24 No. 7, pp. 746-761.

Harris, L.C. and Goode, M.M. (2004), "The four levels of loyalty and the pivotal role of trust: A study of online service dynamics“, Journal of Retailing, Vol. 80 No. 2, pp. 139-158.

Hartley, N. and Green, T. (2017), "Consumer construal of separation in virtual services", Journal of Service Theory and Practice, Vol. 27 No. 2, pp. 358-383.

Hennig-Thurau, T., Gwinner, K.P. and Gremler, D.D. (2002), "Understanding relationship marketing outcomes“, Journal of Service Research, Vol. 4 No. 3, pp. 230-247.

Jin, B., Park, J. and Kim, J. (2008), "Cross-cultural examination of the relationships among firm reputation, e-satisfaction, e-trust, and e-loyalty“, International Marketing Review, Vol. 25 No. 3, pp. 324-337. 
Johns, R. (2012), "Relationship marketing in a self-service context: No longer applicable?" Journal of Relationship Marketing, Vol. 11 No. 2, pp. 91-115.

Johns, R. and Perrott, B. (2008), "The impact of internet banking on business-customer relationships (are you being self-served?)", International Journal of Bank Marketing, Vol. 26 No. 7, pp. 465-482.

Johnson, D.S., Bardhi, F. and Dunn, D.T. (2008), "Understanding how technology paradoxes affect customer satisfaction with self-service technology: The role of performance ambiguity and trust in technology", Psychology \& Marketing, Vol. 25 No. 5, pp. 416-443.

Keh, H. and Pang, J. (2010), "Customer reactions to service separation“, Journal of Marketing, Vol. 74 No. 2, pp. 55-70.

Kinard, B.R. and Capella, M.L. (2006), "Relationship marketing: The influence of consumer involvement on perceived service benefits“, Journal of Services Marketing, Vol. 20 No. 6, pp. 359-368.

Kingshott, R.P. (2006), "The impact of psychological contracts on trust and commitment within supplier-buyer relationships: A social exchange view“", Industrial Marketing Management, Vol. 35 No. 6, pp. 724-739.

Kingshott, R.P. and Pecotich, A. (2007), "The impact of psychological contracts on trust and commitment in supplier-distributor relationships", European Journal of Marketing, Vol. 41 No. 9/10, pp. 1053-1072.

Krishnamurthi, L. and Raj, S.P. (1991), "An empirical analysis of the relationship between brand loyalty and consumer price elasticity“, Marketing Science, Vol. 10 No. 2, pp. 172183.

Kursunluoglu, E. (2014), "Shopping centre customer service: Creating customer satisfaction and loyalty“, Marketing Intelligence and Planning, Vol. 32 No. 4, pp. 528-548.

Li, C.Y. (2015), "Switching barriers and customer retention: Why customers dissatisfied with online service recovery remain loyal", Journal of Service Theory and Practice, Vol. 25 No. 4, pp. 370-393.

Lin, J.S.C. and Hsieh, P.L. (2012), "Refinement of the technology readiness index scale: A replication and cross-validation in the self-service technology context", Journal of Service Management, Vol. 23 No. 1, pp. 34-53.

Lovelock, C. and Gummesson, E. (2004), "Whither services marketing? In search of a new paradigm and fresh perspectives“", Journal of Service Research, Vol. 7 No. 1, pp. 20-41.

Malhotra, N.K., Ulgado, F.M., Agarwal, J., Shainesh, G. and Wu, L. (2005), "Dimensions of service quality in developed and developing economies: Multi-country cross-cultural comparisons", International Marketing Review, Vol. 22 No. 3, pp. 256-278.

McCallum, J.R. and Harrison, W. (1985), "Interdependence in the Service Encounter", in The Service Encounter Managing Employee: Customer Interaction m Service Businesses, Czepiel, J.A., Solomon, M.R. and Surprenant, C.F. (Eds), Lexington Books, Lexington, MA, pp. 35-48. 
McCole, P., Ramsey, E. and Williams, J. (2010), "Trust considerations on attitudes towards online purchasing: The moderating effect of privacy and security concerns", Journal of Business Research, Vol. 63 No. 9, pp. 1018-1024.

Meuter, M.L., Ostrom, A.L., Roundtree, R.I. and Bitner, M.J. (2000), "Self-service technologies: Understanding customer satisfaction with technology-based service encounters", Journal of Marketing, Vol. 64 No. 3, pp. 50-64.

Meuter, M.L., Bitner, M.J., Ostrom, A.L. and Brown, S.W. (2005), "Choosing among alternative service delivery modes: an investigation of customer trial of self-service technologies", Journal of Marketing, Vol. 69 No. 2, pp. 61-83.

Meyer, J. and Herscovitch, L. (2001), "Commitment in the workplace: Toward a general model“, Human Resource Management Review, Vol. 11 No. 3, pp. 299-326.

Michel, S. (2001), "Analyzing service failures and recoveries: A process approach", International Journal of Service Industry Management, Vol. 12 No. 1, pp. 20-33.

Moorman, C., Deshpande, R. and Zaltman, G. (1993), "Factors affecting trust in market research relationships“", Journal of Marketing, Vol. 57 No. 1, pp. 81-101.

Moorman, C., Zaltman, G. and Deshpande, R. (1992), "Relationships between providers and users of market research: The dynamics of trust within and between organizations", Journal of Marketing Research, Vol. 29 No. 3, pp. 314-328.

Morgan, R. and Hunt, S. (1994), "The commitment-trust theory of relationship marketing“, Journal of Marketing, Vol. 58 No. 3, pp. 20-38.

Nicholson, C.Y., Compeau, L.D. and Sethi, R. (2001), “The role of inter-personal liking in building trust in long-term channel relationships", Journal of the Academy of Marketing Science, Vol. 29 No. 1, pp. 3-15.

Oliver, R.L. (1999), “Whence consumer loyalty?” Journal of Marketing, Vol. 63 No. 4, pp. 33-44.

Ostrom, A.L., Parasuraman, A., Bowen, D.E., Patricio, L. and Voss, C.A. (2015), "Service research priorities in a rapidly changing context", Journal of Service Research, Vol. 18 No. 22, pp. 127-159.

Ou, Y.C., Verhoef, P.C. and Wiesel, T. (2016), "The effects of customer equity drivers on loyalty across services industries and firm", Journal of the Academy of Marketing Science, Vol. 45 No. 3, pp. 1-21.

Palmatier, R.W., Dant, R.P., Grewal, D. and Evans, K.R. (2006), "Factors influencing the effectiveness of relationship marketing: A meta-analysis“, Journal of Marketing, Vol. 70 No. 4, pp. 136-153.

Paluch, S. and Blut, M. (2013), "Service separation and customer satisfaction assessing the service separation/customer integration paradox", Journal of Service Research, Vol. 16 No. 3, pp. 415-427. 
Parasuraman, A., Zeithaml, V.A. and Malhotra, A. (2005), "E-S-QUAL: a multiple-item scale for assessing electronic service quality", Journal of Service Research, Vol. 7 No. 3 , pp. 213-233.

Paulssen, M., Roulet, R. and Wilke, S. (2014), "Risk as moderator of the trust-loyalty relationship“, European Journal of Marketing, Vol. 48 No. 5/6, pp. 964-981.

Price, L.L. and Arnould, E.J. (1999), "Commercial friendships: Service provider-client relationships in context", Journal of Marketing, Vol. 63 No. 4, pp. 38-56.

Pritchard, M.P., Havitz, M.E. and Howard, D.R., (1999), “Analyzing the commitment-loyalty link in service contexts“, Journal of the Academy of Marketing Science, Vol. 27 No. 3, pp. 333-348.

Ramaseshan, B., Kingshott, R.P. and Stein, A. (2015), "Firm self-service technology readiness", Journal of Service Management, Vol. 26 No. 5, pp. 751-776.

Rauyruen, P. and Miller, K.E. (2007), "Relationship quality as a predictor of B2B customer loyalty", Journal of Business Research, Vol. 60 No. 1, pp. 21-31.

Reichheld F.F. and Schefter, P. (2000), "E-loyalty: Your secret weapon on the web", Harvard Business Review, Vol. 78 No. 4, pp. 105-113.

Reinartz, W. and Kumar, V. (2002), "The mismanagement of customer loyalty", Harvard Business Review, Vol. 80 No. 7, pp. 86-95.

Sajtos, L., Kreis, H. and Brodie, R., (2015), "Image, brand relationships and customer value: Exploring the moderating role of advertising spending-and labour-intensity in customer loyalty", Journal of Service Theory and Practice, Vol. 25 No. 1, pp.51-74.

Scherer, A., Wünderlich, N.V. and Von Wangenheim, F. (2015), "The value of self-service: Long-term effects of technology-based self-service usage on customer retention", MIS Quarterly, Vol. 39 No. 1, pp. 177-200.

Sheth, J. N. and Parvatiyar, A. (1995), "The evolution of relationship marketing", International Business Review, Vol. 4 No. 4, pp. 397-418.

Shin, H., Ellinger, A.E., Mothersbaugh, D.L. and Reynolds, K.E. (2017), “Employing proactive interaction for service failure prevention to improve customer service experiences", Journal of Service Theory and Practice, Vol. 27 No. 1, pp.164-186.

Sierra, J.J. and McQuitty, S. (2005), "Service providers and customers: Social exchange theory and service loyalty“, Journal of Services Marketing, Vol. 19 No. 6, pp. 392-400.

Singh, J. and Crisafulli, B. (2016), "Managing online service recovery: Procedures, justice and customer satisfaction", Journal of Service Theory and Practice, Vol. 26 No. 6, pp. 764-787.

Sirdeshmukh, D., Singh, J. and Sabol, B. (2002), "Consumer trust, value, and loyalty in relational exchanges“", Journal of Marketing, Vol. 66 No. 1, pp. 15-37. 
Skinner, D., Dietz, G. and Weibel, A. (2013), "The dark side of trust: When trust becomes a 'poisoned chalice'“, Organization, Vol. 21 No. 2, pp. 1-19.

Sousa, R. and Voss, C.A. (2006), 'Service quality in multi-channel service employing virtual channels", Journal of Service Research, Vol. 8 No. 4, pp. 356-371.

Steenkamp, J. and Baumgartner, H. (1998), "Assessing measurement invariance in crossnational consumer research“, Journal of Consumer Research, Vol. 25 No. 1, pp. 78-107.

Swan, J.E. and Nolan, J.J. (1985), "Gaining customer trust: A conceptual guide for the salesperson”, Journal of Personal Selling \& Sales Management, Vol. 5 No. 2, pp. 39-48.

Tabachnick, B.G. and Fidell, L. (1996), Using Multivariate Statistics, 3rd ed., HarperCollins, New York, NY.

Tate, W.L., Ellram, L.M. and Brown, S.W. (2009), "Offshore outsourcing of services: A stakeholder perspective”, Journal of Service Research, Vol. 12 No. 1, pp. 56-72.

Thibaut, J.W. and Kelley, H.H. (1959), Social Psychology of Groups, John Wiley and Sons, New York, NY.

Tsiotsou, R.H. (2016), "The social aspects of consumption as predictors of consumer loyalty online vs offline services“, Journal of Services Management, Vol. 27 No. 2, pp. 91-116.

Turnbull, P., Ford, D. and Cunningham, M. (1996), "Interaction, relationships and networks in business markets: An evolving perspective“", Journal of Business \& Industrial Marketing, Vol. 11 No. 3/4, pp. 44-62.

Verhoef, P.C., Lemon, K.N., Parasuraman, A., Roggeveen, A., Tsiros, M. and Schlesinger, L.A. (2009), "Customer experience creation: Determinants, dynamics and management strategies", Journal of Retailing, Vol. 85 No. 1, pp.31-41.

van Esterik-Plasmeijer, P. W., \& van Raaij, W. F. (2017), "Banking system trust, bank trust, and bank loyalty", International Journal of Bank Marketing, Vol. 35 No. 1, pp. 97-111.

Vargo, S.L. and Lusch, R.F. (2004), "Evolving to a new dominant logic for marketing“, Journal of Marketing, Vol. 68 No. 1, pp. 1-17.

Vargo, S.L. and Lusch, R.F. (2008), "Service-dominant logic: Continuing the evolution", Journal of the Academy of Marketing Science, Vol. 36 No. 1, pp. 1-10.

Verma, V., Sharma, D. and Sheth, J. (2016), "Does relationship marketing matter in online retailing? A meta-analytic approach“, Journal of the Academy of Marketing Science, Vol. 44 No. 2, pp. 206-217.

Yap, K.B., Wong, D.H., Loh, C. and Bak, R. (2010), "Offline and online banking-where to draw the line when building trust in e-banking?" International Journal of Bank Marketing, Vol. 28 No. 1, pp. 27-46.

Walsh, G., Schaarschmidt, M. and Ivens, S. (2018), "Assessing the effects of multichannel service provider corporate reputation on customer new product adoption and RFM value", Journal of Service Management, Vol. 28 No. 4, 680-702. 
World Retail Banking Report, (2013), Capgemini and EFMA, available at: http://www.capgemini.com/resource-file-access/resource/pdf/wrbr_2013_0.pdf (accessed 9 June 2014).

Yen, H.J.R. and Gwinner, K.P. (2003), "Internet retail customer loyalty: The mediating role of relational benefits", International Journal of Service Industry Management, Vol. 14 No. 5, pp. 483-500.

Yilmaz, C., Sezen, B. and Ozdemir, O. (2005), "Joint and interactive effects of trust and (inter) dependence on relational behaviors in long-term channel dyads", Industrial Marketing Management, Vol. 34 No. 3, pp. 235-248.

Yim, C.K., Tse, D.K. and Chan, K.W. (2008), "Strengthening customer loyalty through intimacy and passion: Roles of customer-firm affection and customer-staff relationships in services“, Journal of Marketing Research, Vol. 45 No. 6, pp. 741-756.

Zeithaml, V.A., Berry, L. and Parasuraman, A. (1996), "The behavioral consequences of service quality“, Journal of Marketing, Vol. 60 No. 2, pp. 31-46.

Zeithaml, V.A., Parasuraman, A. and Berry, L.L. (1985), "Problems and strategies in services marketing", Journal of Marketing, Vol. 49 No. 2, pp. 33-46.

Zhou, Y., Tsang, A.S.L., Huang, M. and Zhou, N. (2014), "Group service recovery strategies effectiveness: The moderating effects of group size and relational distance", Journal of Business Research, Vol. 67 No. 11, pp. 2480-2485. 
Figure 1 - Conceptual Model

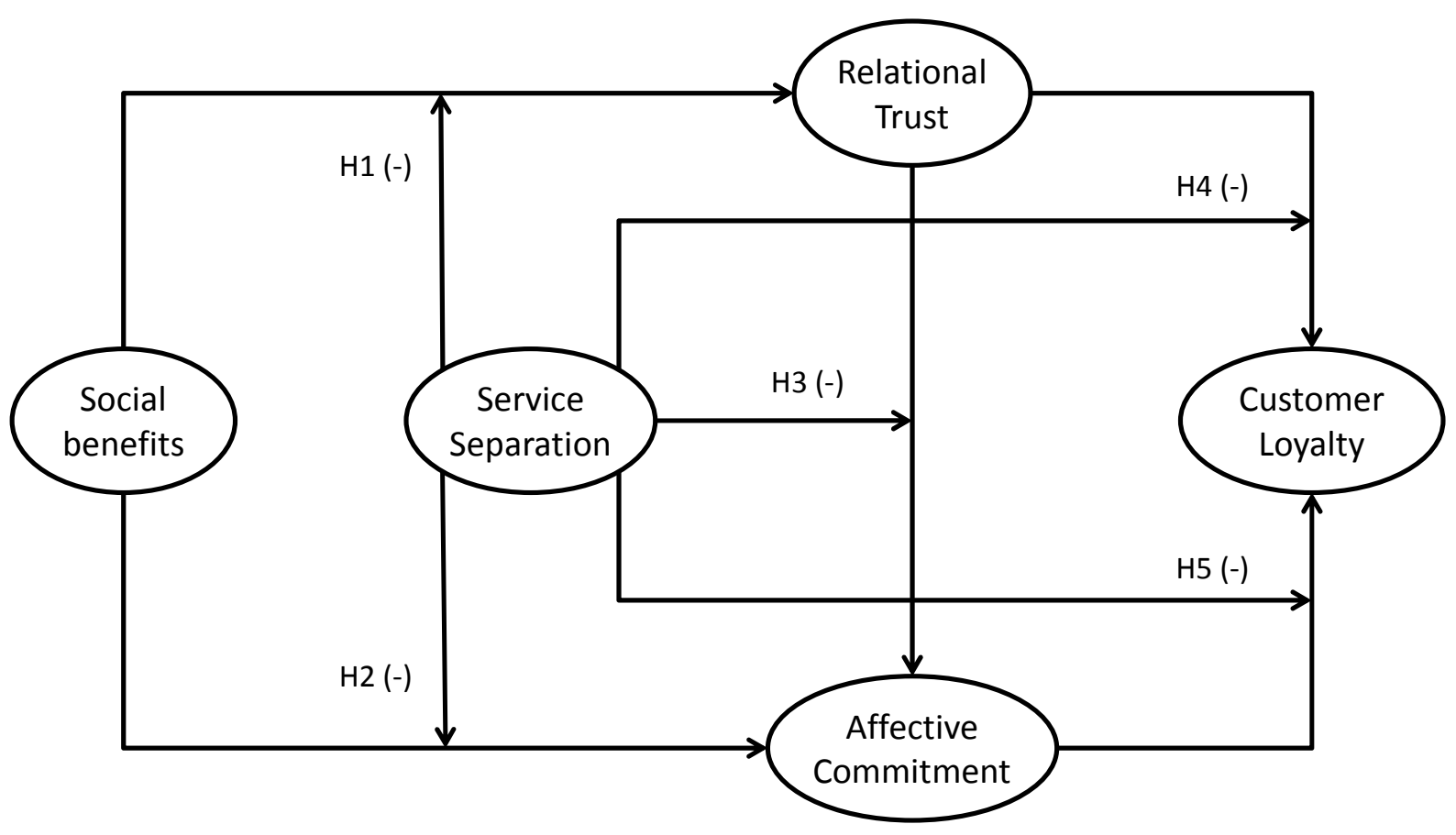


Table 1: Scale Items and Standardized Factor Loadings

\begin{tabular}{|c|c|c|c|c|c|c|}
\hline \multirow[b]{2}{*}{ Items } & \multicolumn{3}{|c|}{ Unseparated } & \multicolumn{3}{|c|}{ Separated } \\
\hline & $\lambda$ & $\mathbf{M}$ & SD & $\lambda$ & $\mathbf{M}$ & SD \\
\hline Social Benefits & & 4.38 & .72 & & 3.45 & .75 \\
\hline I enjoy social aspects of the relationship with my bank. & .92 & 4.43 & .83 & .65 & 3.22 & .77 \\
\hline I am familiar with the employees who serve me at my bank. & .92 & 4.42 & .70 & .81 & 3.39 & .72 \\
\hline I am recognized by certain employees in my bank. & .89 & 4.55 & .66 & .91 & 3.65 & .74 \\
\hline I have developed a friendship with my bank's employees. & .86 & 4.22 & .57 & .86 & 3.42 & .67 \\
\hline My bank’s employees know my name. & .80 & 4.30 & .89 & .85 & 3.57 & .76 \\
\hline Relational Trust & & 4.90 & .66 & & 4.36 & .79 \\
\hline I feel that my bank is always faithful. & .84 & 5.00 & .62 & .88 & 4.41 & .68 \\
\hline My bank can be trusted completely. & .84 & 4.95 & .58 & .87 & 4.45 & .74 \\
\hline My bank is always perfectly honest with me. & .89 & 4.86 & .64 & .90 & 4.34 & 1.09 \\
\hline I can rely on my bank to do what is right. & .87 & 4.94 & .58 & .89 & 4.22 & .78 \\
\hline My bank has high integrity. & .82 & 4.72 & .81 & .92 & 4.34 & .81 \\
\hline At times, my bank cannot be trusted. & .78 & 4.91 & .65 & .82 & 4.42 & .61 \\
\hline Affective Commitment & & 4.55 & .78 & & 4.00 & 1.02 \\
\hline I feel a strong sense of belonging to my bank. & .76 & 4.68 & .99 & .72 & 4.06 & .88 \\
\hline I want to remain a customer of my bank more than other banks. & .88 & 4.58 & .69 & .90 & 4.24 & 1.20 \\
\hline I feel emotionally attached to my bank. & .88 & 4.50 & .72 & .77 & 3.56 & 1.29 \\
\hline I really like doing business with my bank. & .88 & 4.57 & .68 & .89 & 4.23 & .84 \\
\hline I have developed a closer business relationship with my bank. & .81 & 4.39 & .63 & .80 & 3.94 & .76 \\
\hline Customer Loyalty & & 4.64 & .65 & & 4.12 & .93 \\
\hline The likelihood of me trying other banks' services is very high.* & .76 & 4.54 & .69 & .81 & 3.98 & .63 \\
\hline I think there is a great chance of me staying with my bank. & .76 & 4.70 & .78 & .89 & 4.33 & 1.02 \\
\hline I believe that I have a very strong relationship with my bank. & .89 & 4.59 & .48 & .87 & 4.07 & .89 \\
\hline I am very likely to switch to another bank in the near future.* & .74 & 4.71 & .44 & .87 & 4.10 & 1.08 \\
\hline
\end{tabular}

$\lambda=$ Standardized Factor Loadings; $M=$ Mean; $\mathrm{SD}=$ Standard Deviation 
Table 1: Correlation Tables and Discriminant Validity

\begin{tabular}{|c|c|c|c|c|c|c|c|c|}
\hline & Constructs & $\begin{array}{c}\text { Social } \\
\text { Benefits }\end{array}$ & $\begin{array}{c}\text { Relational } \\
\text { Trust }\end{array}$ & $\begin{array}{c}\text { Customer } \\
\text { Loyalty }\end{array}$ & $\begin{array}{c}\text { Affective } \\
\text { Commitment }\end{array}$ & $\mathbf{M}$ & SD & CR \\
\hline \multirow{4}{*}{ 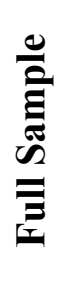 } & Social Benefits & .87 & & & & 3.92 & .73 & .92 \\
\hline & Relational Trust & .53 & .88 & & & 4.63 & .72 & .95 \\
\hline & Customer Loyalty & .50 & .56 & .84 & & 4.28 & .91 & .88 \\
\hline & Affective Commitment & .52 & .61 & .62 & .85 & 4.38 & .78 & .91 \\
\hline \multirow{4}{*}{ 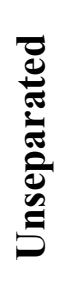 } & Social Benefits & .90 & & & & 4.38 & .72 & .94 \\
\hline & Relational Trust & .76 & .85 & & & 4.90 & .66 & .93 \\
\hline & Customer Loyalty & .64 & .64 & .80 & & 4.55 & .78 & .84 \\
\hline & Affective Commitment & .66 & .70 & .57 & .86 & 4.64 & .65 & .92 \\
\hline \multirow{4}{*}{ 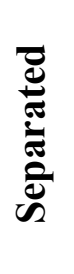 } & Social Benefits & .83 & & & & 3.45 & .75 & .90 \\
\hline & Relational Trust & .38 & .89 & & & 4.36 & .79 & .95 \\
\hline & Customer Loyalty & .39 & .50 & .85 & & 4.00 & 1.02 & .89 \\
\hline & Affective Commitment & .43 & .56 & .61 & .84 & 4.12 & .93 & .91 \\
\hline
\end{tabular}

Note: Square root of Average Variance Explained (AVE) on the diagonal. $\mathrm{M}=$ Mean; $\mathrm{SD}=$ Standard Deviation; $\mathrm{CR}=$ Composite Reliability 
Table 2: Hypotheses Tests

\begin{tabular}{|c|c|c|c|c|c|c|c|}
\hline Model & Unseparated & Separated & $\chi^{2}$ & $d f$ & $\Delta \chi^{2}$ & $\Delta d f$ & Result \\
\hline Baseline (Unconstrained) Model & & & 658.01 & 316 & & & \\
\hline Constrained Model & & & 686.52 & 321 & $28.51^{* * *}$ & 5 & \\
\hline H1: Social Benefits $\rightarrow$ Relational Trust & $.77^{* * *}$ & $.38^{* * *}$ & 677.37 & 317 & $19.36^{* * *}$ & 1 & Supported \\
\hline H2: Social Benefits $\rightarrow$ Affective Commitment & $.32^{* * *}$ & $.22^{* *}$ & 662.05 & 317 & $4.04^{*}$ & 1 & Supported \\
\hline H3: Relational Trust $\rightarrow$ Affective Commitment & $.44^{* * *}$ & $.37^{* * *}$ & 660.16 & 317 & 2.15 & 1 & Not supported \\
\hline H4: Relational Trust $\rightarrow$ Customer Loyalty & $.51^{* * *}$ & $.26^{* * *}$ & 665.85 & 317 & $7.84^{* *}$ & 1 & Supported \\
\hline H5: Affective Commitment $\rightarrow$ Customer Loyalty & $.48^{* * *}$ & $.24^{* * *}$ & 673.77 & 317 & $15.76^{* * *}$ & 1 & Supported \\
\hline
\end{tabular}

